\title{
SECTORAL RISK ASSESSMENT: A CASE OF THE LATVIAN FORESTRY SECTOR
}

\author{
Irina Voronova ${ }^{1}$, Vladimirs Shatrevich ${ }^{2}$, \\ Department of Innovation and Business Management, RTU, Kalnciema street 6, Riga, Latvia, \\ E-mails: ${ }^{1}$ irina.voronova@ rtu.lv; ${ }^{2}$ vladimirs.satrevics@ rtu.lv (corresponding author)
}

Received 04 March 2020; accepted 06 May 2020

\begin{abstract}
The present study provides an analysis of sectoral risk in the forestry sector and presents an overview of multiple-criteria decision analysis (MCDA) for sector development assessment. The main aim of the paper is to determine the macroeconomic indicators and to assess sectorial risk, which is caused by unexpected macroeconomic and market changes. The paper presents a methodological framework for the analysis of sectoral level risk to assess the probability of the stable development of the industry and to determine the risk for the forestry sector (industry). Based on expert opinions and analytic hierarchy process (AHP), the authors have identified and evaluated macroeconomic industry-level data indicators (factors) used to determine the development of the forestry sector. An analysis matrix with the defined and verified indicators (factors) is presented; the comparison between sectoral inicators and sectoral volatility is shown. In order to combine industry development indicators (factors) expressed in different units of measurement and to establish a comprehensive indicator of industry development, the statistical standardisation (normalisation) of indicators is performed.
\end{abstract}

Keywords: quantitative analysis, sectoral risk, scoring methods, AHP, forestry sector.

JEL Classification: C53, C61, L16, L22, O11, O21.

\section{Introduction}

The concept of sectoral risk evaluation is usually based on the major domain - systemic risk, which is caused by unexpected macroeconomic and market changes. Companies show positive correlations within and across industries, and dependence structure might by driven by sectoral (systematic) risk factors. Risk is an irremediable part of individual and organisational decision-making process and, in many situations, risk taking seems to be the only available strategy to cope with risk (Hora \& Klassen, 2013).

Based on the review of the literature concerning sectoral risk, it is argued that quite frequently sectoral risk is defined as the average risk of enterprises conducting operations in the sector (Nehrebecka, 2018). Therefore, it is important to analyse the factors that can determine or explain credit risk, with the aim of enabling managers to mitigate it (Vivel-Búa et al., 2018). The mechanism of how the sectors in the economic system influence each other is not clearly defined, and the same refers to indicators within sectors due to their dynamic nature. There are few studies about economic risk at the sectoral level, which is important for risk prewarning. Since physicists have made significant progress towards understanding the structure and functioning of complex networks, which have been proven to be effective in analysing economic phenomena, the complex network method has been widely used in economic studies (Zhang, 2018). Allen and Gale (2000) study financial contagions by employing a complex network model, which is the first to apply a complex network method to investigate the complex economic system.

The complex network models have also some drawbacks for small companies that are trying to develop a sophisticated risk model. It is a tough and challenging task to address this problem by traditional ways such as based on experts' judgements (Zhu et al., 2018). It is also true when experts determine priorities among factors and alternatives in the case of a huge number of factors. Experts involved in the evaluation process need to perform a lot of accurate identification procedures among factors that could be very exhausting. Another issue is the evaluation uncertainty, when an expert cannot quantify relative influence or priority of the factors very accurately and spends a lot of time on the evaluation process. In this case, experts could be allowed to use a fuzzy scale (the average opinion of group of experts is a fuzzy value obtained by the aggregation of individual opinions). Small and medium-sized enterprises (SMEs) need a simple yet effective framework for the analysis 
of risk at the sectoral level, thus adjusting operational risks. The ability to answer such questions and benchmark one's operational risk performance is especially important in emerging markets, where it is recognised that companies tend to be exposed to a greater operational risk, e.g., systemic risks, fraud etc. (Ray \& Das, 2010; Smimou, 2014).

The paper overviews sectoral risk assessment approaches defining the assessment methodology. It then explains an MCDA method - a hierarchical analysis method (AHP). After that the step-by-step methodology for industry indicator identification and formation of a Group of Experts is discussed. An analysis matrix to be assessed by carefully defining and verifying the indicators (factors) is provided and, finally, conclusions are made.

\section{General rules and characteristics assessing sectoral risk}

Sectoral risk assessment is associated with two main approaches used to define sectoral risk. The first approach to determine the risk focuses on the probability of losses due to changes in the industry and the degree of these changes both internally and in comparison with other industries (Tapman, 2002, p. 61). An example of assessing industry risk based on this definition is an approach to assessing industry risks using input-output structure and status coefficients (Zhang, 2018).

The study covers 71 sectors in America. However, according to the authors, there is no clear indication of the relationship between the status coefficients and the risk of industry development. Another approach to assessing industry risks is the approach used in assessing and calibrating the global risk of the rating industry - Standard \& Poor's as one of three assessments along with a country assessment and a competitive position. Two factors are used to assess the global industry risk - the cycle of development of the industry and competitiveness. For this purpose, statistical data on the development of industries (for example, industry revenues, EBITDA) and k-means clustering are used. This approach to risk assessment also relies on a certain dimension of defining risk as a change in the industry due to cyclicality and competitiveness. The second approach to the definition of sectoral risk is the definition containing risk dimensions such as the activities of individual enterprises - "sectorial risk is defined as the average risk of enterprise conducting operations in the sector" (Nehrebecka, 2018, p. 3).

Nehrebecka (2018) provides an overview of the approaches to assessing sector-specific risk based on the definition of risk using risk dimension through the activities of enterprises in the sector (e.g., sectoral concentration (Accornero et al., 2015; Düllmann \& Masschelein, 2007). Nehrebecka (2018) present a sectoral risk analysis approach using the probability of default $(P D)$ model. Risk assessment is based on two components: quantitative component (financial factors) and qualitative part (behavioural factors). Financial factors are evaluated using financial capacity and risk of bankruptcy. The narrowing method is similar to the PD model for assessing the credit risk of a banking portfolio, in which borrowers are replaced by industries.

There are also various approaches to quantifying the significance of indicators (factors) used to assess risk - from fairly simple to sophisticated.

As a systematic method, the general rules for factor assessment are used. If indicators (factors) $R_{i}^{a}$ have one meaning, then they have the same effect on the peformance indicator, which comprehensively describes the state of the industry. If the factors are of equal importance, the importance of the factors is determined by formula (1):

$$
w\left(F_{i}\right)=w_{i}=\frac{1}{N} .
$$

If indicators (factors) $F_{i}$ have different meanings, then they have different effects on the performance indicator, which comprehensively describes the state of the industry. There are two options for calculating the importance of an indicator (factor). First, if the analyst is able to rank factors in descending order of importance (steady decline), the importance of the factors is determined by Peter C. Fishburn's formula.

$$
w\left(F_{i}\right)=w_{i}=\frac{2\left(N-j\left(F_{i}\right)+1\right)}{(N+1) \cdot N},
$$

where $j\left(F_{i}\right)$ is the position number of the $F_{i}$ indicator/factor in ranking series.

The next approach is to evaluate indicators (factors) using the method of pairwise comparisons with rating on a scale with different grounds: important (1) and less important (0) or on a scale with a base of 2 or 4 , where 2 - an important indicator and $1-$ an indicator of equal importance. The formed matrix (see Table 1) of expert assessment allows determining the significance of indicators using standardisation (the ratio of the total score of indicators in a row to the total score of all matrix estimates). An example of this approach is given in the works by (Cvetkova, 2010).

If, from the analyst's point of view, the impact of factors on the development of the industry is not 
steadily declining, in this case it is advisable to use a factor expert assessment method with the following factor rationing or hierarchical analysis method (AHP). MCDA methods allow ranking the determined strategies and factors.

Table 1. Expert factor significance matrix

\begin{tabular}{|c|c|c|c|c|c|c|c|c|c|}
\hline \multirow{2}{*}{ No. } & $\begin{array}{c}\text { Indicator } \\
\text { (factor) }\end{array}$ & \multicolumn{6}{|c|}{$\begin{array}{c}\text { Indicator (factor) } \\
\text { assessment (score) }\end{array}$} & \multicolumn{3}{c|}{$S S=\sum_{i=1}^{n} B_{i}$} & $\begin{array}{c}\text { Factor } \\
\text { Importance } \\
w\left(F_{i}\right)=w_{i}\end{array}$ \\
\hline & & $F_{1}$ & $F_{2}$ & $F_{3}$ & $\ldots$ & $F_{i}$ & $F_{n}$ & & \\
\hline 1 & $F_{1}$ & 1 & 2 & 1 & & 1 & 0 & $S_{1}$ & $S_{1} / S S$ \\
\hline 2 & $F_{2}$ & 0 & 1 & & & & & $S_{2}$ & \\
\hline 3 & $F_{3}$ & 1 & & 1 & & & & $S_{3}$ & \\
\hline$\ldots$ & $\ldots$ & & & & 1 & & & $\ldots$ & \\
\hline$i$ & $F_{i}$ & 1 & & & & 1 & & $S_{i}$ & \\
\hline$n$ & $F_{n}$ & 2 & & & & & 1 & $S_{n}$ & \\
\hline $\begin{array}{l}\text { Importance Weight - The } \\
\text { importance or significance of } \\
\text { factors in the overall value of } \\
\text { industry development index. }\end{array}$ & & Sum & $S S=\sum_{i=1}^{n} S_{i}$ & 1 \\
\hline
\end{tabular}

AHP, as a hierarchical weighted decision analysis method proposed by Saaty (Saaty, 1989), is the most widely used MCDA method that combines qualitative analysis with quantitative analysis (Ho, 2008).

$$
A w=\lambda_{\text {max }} w
$$

where $\lambda_{\max }$ is the largest or principle eigenvalue of the pairwise comparison matrix and $w$ is the corresponding principle eigenvector.

The $C R$ (consistency ratio) of matrix $A$ is used to check judgment inconsistency. $C R=C I / R I$, where $C I=\left(\lambda_{\max }-n\right) /(n-1)$ and $\lambda_{\max }$ is the maximal eigenvalue of $A$. $R I$ (random index) is an experimental value, which depends on $n$ (Saaty 1989). The AHP uses a 9-point Saaty scale. According to the scale principles in Table 2, a comparison of pairs is derived in the matrix.

Table 2. The fundamental scale of AHP (Saaty, 1989)

\begin{tabular}{|c|l|}
\hline $\begin{array}{c}\text { Intensity of Im- } \\
\text { portance }\end{array}$ & \multicolumn{1}{c|}{ Definition } \\
\hline 1 & Equal importance \\
\hline 3 & Moderate importance \\
\hline 5 & Strong importance \\
\hline 7 & Very strong importance \\
\hline 9 & Absolute importance \\
\hline $2,4,6,8$ & Used to express intermediate values \\
\hline reciprocals & $\begin{array}{l}\text { The scale between } x_{i} \text { and } x_{j} \text { is } r_{i j}= \\
1 / r_{j i}\end{array}$ \\
\hline
\end{tabular}

ANP is a newer tool used to solve multicriteria problems. It is a type of system decision analysis, which combines qualitative and quantita- tive factors based on the AHP (Saaty, 2004). The hierarchical structure of the AHP is formed using a top-down linear structure, whereas the ANP network structure is a nonlinear structure with factors placed in all directions (Sevkli et al., 2012). The steps of the proposed framework are partially adapted from the best practices in the latest literature (Arsić et al., 2018, 2017; Cayir Ervural et al., 2018; Grošelj \& Zadnik Stirn, 2015; Sevkli et al., 2012; Yüksel \& Dağdeviren, 2007).

ANP not only solves the issues that can be solved by AHP but also considers the interaction with and dependency on each influencing factor in decision-making (Chen \& Yang, 2011).

The AHP is also used to assess entrepreneurial risks and project risks. A brief review of the methods for assessing industry risks has led to the conclusion that the methods for assessing risks are associated with the determination of industry risk and are carried out using two to three factors with 3-15 indicators. Since with a large number of indicators they have different units of measurement, their rationing (normalisation) is used.

\section{Methodology}

Based on the synthesis of studies (Evangelista et al., 2015; Ito \& Shimizu, 2015; Počs, 2016) factor indicators (factors) are predetermined in the industry risk assessment proposed to experts for selection (e.g., Table 2). After refining indicators (factors) by experts, only 10 of them have remained (Table 3). All indicators must be reliable (validated) for the study; therefore, it is proposed to use macroeconomic industry-level data indicators (factors) available in the Central Statistical Bureau for expert evaluation. The method determines the indicators (factors) that will be used to assess the industry over different time periods.

Table 3. Data collection table

\begin{tabular}{|c|c|c|c|c|c|}
\hline \multirow[b]{2}{*}{$\begin{array}{l}\text { Indicator } \\
\text { (factor) }\end{array}$} & \multirow[b]{2}{*}{$\begin{array}{l}\text { Data } \\
\text { source }\end{array}$} & \multicolumn{4}{|c|}{ Indicator (factor) importance } \\
\hline & & $\begin{array}{c}2015 \\
\text { (base } \\
\text { period) }\end{array}$ & 2016 & $\ldots$ & 2018 \\
\hline 1. $F_{1}$ & $\begin{array}{l}\text { Central } \\
\text { Statistical } \\
\text { Bureau }\end{array}$ & & & & \\
\hline 2. $F_{2}$ & $\ldots$ & & & & \\
\hline$\ldots$ & $\ldots$ & & & & \\
\hline$i . F_{i}$ & $\ldots$ & & & & \\
\hline n. $F_{n}$ & $\ldots$ & & & & \\
\hline
\end{tabular}


The number of factors can be increased by using the factor tree or sub-factors (HAM). The proposed framework used in the present study is shown in Table 3 (see Table 4 for final version).

The authors acknowledge that there are ecosystem specific factors affecting the forestry sector, such as a variety of ecosystem services and underpinning biodiversity for operating successfully. These ecosystems are, nonetheless, affected by company operations and other indirect activities (D'Amato et al., 2015).

Research interest has recently grown on the linkages between the ecosystem service framework and business sustainability disclosure (Aguilar et al.,
2013; Boulter, 2011). However, we focus on sector development indicators (factors). Data collection is performed using industry development indicators, which may be absolute or expert evaluated over the analysis period (3-5 years). The base or normative value of each factor $\left(F_{i}\right)$ is deteremined.

\section{Sectoral assessment: Case of forestry sector of Latvia}

During the study, specific factors for the development of the industry, such as reforestation, have not been included.

Table 4. Forestry sector indicators (factors) (source: Central Statistical Bureau, 2020)

\begin{tabular}{|c|c|c|c|c|c|c|c|c|c|c|c|}
\hline \multirow[b]{2}{*}{ No. } & \multirow[b]{2}{*}{ Data source } & \multicolumn{7}{|c|}{ Indicator (factor) importance } & \multirow[b]{2}{*}{ Average } & \multirow[b]{2}{*}{ STDEV.P } & \multirow[b]{2}{*}{$\begin{array}{l}\text { Var. } \\
\text { coef }\end{array}$} \\
\hline & & $\begin{array}{c}2012 \\
\text { (base) }\end{array}$ & $\begin{array}{l}2013 \\
\text { PF1 }\end{array}$ & $\begin{array}{l}2014 \\
\text { PF2 }\end{array}$ & $\begin{array}{l}2015 \\
\text { PF3 }\end{array}$ & $\begin{array}{l}2016 \\
\text { PF4 }\end{array}$ & $\begin{array}{l}2017 \\
\text { PF5 }\end{array}$ & $\begin{array}{l}2018 \\
\text { PF6 }\end{array}$ & & & \\
\hline 1 & $\begin{array}{l}\text { Total value } \\
\text { added, at cur- } \\
\text { rent prices, } \\
\text { thsd. euro }\end{array}$ & 286802 & 349994 & 393369 & 359553 & 357128 & 392741 & 356597.8 & 356597.8 & 30786.63 & 0.09 \\
\hline 2 & $\begin{array}{l}\text { Export, thsd } \\
\text { euro }\end{array}$ & 93078 & 100044.2 & 92500 & 79477 & 84345 & 86088 & 174327 & 101408.5 & 28448.64 & 0.28 \\
\hline 3 & $\begin{array}{l}\text { Non-financial } \\
\text { investments in } \\
\text { intangible as- } \\
\text { sets (at current } \\
\text { prices), thous. } \\
\text { euro }\end{array}$ & 124933 & 129864 & 151884 & 84713 & 127746 & 134129 & 125544.8 & 125544.8 & 17530.52 & 0.14 \\
\hline 4 & $\begin{array}{l}\text { Average num- } \\
\text { ber of employ- } \\
\text { ees in norwork- } \\
\text { ing time units }\end{array}$ & 7671 & 7856 & 8340 & 8275 & 8231 & 8425 & 8964 & 8251.714 & 360.5488 & 0.04 \\
\hline 5 & $\begin{array}{l}\text { Net turnover of } \\
\text { enterprises by } \\
\text { kind of eco- } \\
\text { nomic activity, } \\
\text { mln. euro }\end{array}$ & 781.1 & 860.5 & 921.7 & 882.7 & 910.3 & 945.5 & 1328.3 & 947.1571 & 152.6918 & 0.16 \\
\hline 6 & $\begin{array}{l}\text { Economic prof- } \\
\text { itability (before } \\
\text { tax), } \%\end{array}$ & 8.629 & 9.207 & 9.641 & 7.197 & 5.595 & 7.265 & 13.048 & 8.654571 & 2.061477 & 0.24 \\
\hline 7 & $\begin{array}{l}\text { Total liquidity, } \\
\text { times }\end{array}$ & 1.384 & 1.344 & 1.498 & 1.482 & 1.305 & 1.287 & 1,584 & 1.412 & 0.096412 & 0.07 \\
\hline 8 & $\begin{array}{l}\text { Average } \\
\text { monthly gross } \\
\text { earnings of } \\
\text { employees, } \\
\text { euro }\end{array}$ & 748 & 785 & 831 & 880 & 949 & 1030 & 1124 & 906.7143 & 117.6071 & 0.13 \\
\hline 9 & $\begin{array}{l}\text { Liabilities as a } \\
\text { percentage of } \\
\text { the balance } \\
\text { sheet }\end{array}$ & 0.276 & 0.245 & 0.25 & 0.257 & 0.262 & 0.264 & 0.264 & 0.259714 & 0.008842 & 0.03 \\
\hline 10 & $\begin{array}{l}\text { Turnover of all } \\
\text { assets, times }\end{array}$ & 0.722 & 0.698 & 0.702 & 0.633 & 0.621 & 0.612 & 0.813 & 0.685857 & 0.061578 & 0.09 \\
\hline \multicolumn{10}{|c|}{ The indicator of the volatility existence (Xe) of factors, taking into account volatility, is from $5 \%$ to $15 \%$} & $\mathrm{Xe}$ & 0.13 \\
\hline
\end{tabular}




\subsection{Forming a group of experts}

To assess the industry risk, a group of experts has been formed. It comprised specialists of the company and specialist consultants. The number of experts in accordance with the principles of Gestalt (Merton et al., 1990) should be in the limit of 10 people (usually $7 \pm 2$ ). Selection of candidates for a group of experts can be carried out by various methods (Ivlev et al., 2015). The authors of the present study propose developing a simple method of self-assessment and calculation of the coefficient of competence.

Candidates (initiating the development of a strategic development plan) have been asked to answer the question: How do you assess the level of skills in the field of analysis of industry development? The results of the survey of candidates for experts and calculation of the competence of experts and a group of experts are given in Table 5. The group of experts has been formed of five experts and their competence has been more than the normative value $\left(K_{i}=0.67\right)$ (Postnikov \& Spiridonov, 2013). The authors have used a geometric mean method (GMM), also called the approximate eigen value.

Table 5. The formation of a group of experts

\begin{tabular}{|c|c|c|c|c|c|c|c|c|c|c|c|}
\hline \multirow{2}{*}{ 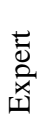 } & \multicolumn{3}{|c|}{ Criterion 1} & \multicolumn{3}{|c|}{ Criterion 2} & \multicolumn{3}{|c|}{ Criterion 3} & \multirow{2}{*}{$K_{i}$} & \multirow{2}{*}{ 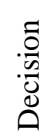 } \\
\hline & 1 & 0.5 & 0 & 1 & 0.5 & 0 & 1 & 0.5 & 0 & & \\
\hline E1 & & 1 & & 1 & & & & 1 & & 0.67 & + \\
\hline E2 & & 1 & & 1 & & & & 1 & & 0.67 & + \\
\hline E3 & 1 & & & 1 & & & 1 & & & 1.00 & + \\
\hline E4 & & 1 & & 1 & & & 1 & & & 0.83 & + \\
\hline E5 & & 1 & & & 1 & & & & 1 & 0.33 & - \\
\hline E6 & & 1 & & 1 & & & 1 & & & 0.67 & + \\
\hline E7 & 1 & & & & 1 & & & & 1 & 0.50 & - \\
\hline
\end{tabular}

Rule for the decision to include (+) / not include (-) an expert in the group, where:

$i$-assessment of the competence of the group of experts

if $0.67 \leq K_{i} \leq 1.00$ an expert is added to the group

if $K_{i}<0.67$ an expert is not added to the group.

Assessment of the competence of the group of experts $-K_{i}$

Assessment of the competence of the group of experts

$$
K_{k g}=\frac{1}{n_{x}} \sum_{i=1}^{n_{x}} K_{i}=0.76
$$

where: $K_{i}$-competence assessment of $i$ expert; $n_{x}$ - the number of selected experts in the group

Assessment criteria:

1. Theoretical knowledge of strategic management. 2. Practical experience of strategy formulation. 3. Conceptual skills.

\subsection{The main steps of the proposed framework}

The main steps of the proposed methodology and its specific implementation are given below.

Step 1. To predetermine 10-15 indicators (factors) that will be used to assess the industry over different time periods.

Step 2. To form a group of experts and/or decision makers (Table 5). A series of focus group meetings has been conducted with company owners and other experts to determine their opinions and preferences with regard to the nature of the indicators for industry and the evaluation methods of those indicators.

Step 3. To assess an analysis matrix by carefully defining and verifying the indicators (factors). In order to combine industry development indicators (factors) expressed in different units of measurement and to establish a comprehensive indicator of industry development, the statistical standardisation (normalisation) of indicators should be performed.

Standardisation (normalisation) of each indicator used to measure industry development should be performed expressing or assuming the volatility of factors. Calculation of the significance (importance) of standardised factors $\left(F_{i}\right)$ :

$\begin{cases}1 & \text { if } R_{f_{i}} \cdot\left(1-X_{e}\right)>R_{b i} \\ F_{i}=\frac{R_{f_{i}} \cdot\left(1+X_{e}\right)-R_{b i}}{2 \cdot R_{f_{i}} \cdot X_{e}} & \text { if } R_{f_{i}} \cdot\left(1+X_{e}\right)>R_{b i} \\ 0 & \text { if } R_{f_{i}} \cdot\left(1+X_{e}\right)<R_{b i}\end{cases}$

Table 6. Expert factor significance matrix for the forestry sector (industry) using AHP

\begin{tabular}{|c|c|c|c|c|c|c|c|c|c|c|c|c|}
\hline $\mathrm{No}$ & 1 & 2 & 3 & 4 & 5 & 6 & 7 & 8 & 9 & 10 & $\mathrm{EV}$ & $w_{i}$ \\
\hline 1 & 1.00 & 1.00 & 2.00 & 5.00 & 4.00 & 0.50 & 2.00 & 4.00 & 2.00 & 3.00 & 0.43 & 0.16 \\
\hline 2 & 1.00 & 1.00 & 3.00 & 5.00 & 4.00 & 0.50 & 3.00 & 4.00 & 3.00 & 4.00 & 0.51 & 0.19 \\
\hline 3 & 0.50 & 0.33 & 1.00 & 4.00 & 3.00 & 0.50 & 1.00 & 3.00 & 1.00 & 2.00 & 0.26 & 0.09 \\
\hline 4 & 0.20 & 0.20 & 0.25 & 1.00 & 0.50 & 0.25 & 0.25 & 0.50 & 0.33 & 0.33 & 0.07 & 0.03 \\
\hline 5 & 0.25 & 0.25 & 0.33 & 2.00 & 1.00 & 0.25 & 0.33 & 1.00 & 0.33 & 0.50 & 0.10 & 0.04 \\
\hline 6 & 2.00 & 2.00 & 2.00 & 4.00 & 4.00 & 1.00 & 2.00 & 4.00 & 3.00 & 3.00 & 0.56 & 0.21 \\
\hline 7 & 0.50 & 0.33 & 1.00 & 4.00 & 3.00 & 0.50 & 1.00 & 1.00 & 1.00 & 2.00 & 0.24 & 0.09 \\
\hline 8 & 0.25 & 0.25 & 0.33 & 2.00 & 1.00 & 0.25 & 1.00 & 1.00 & 0.33 & 0.50 & 0.12 & 0.04 \\
\hline 9 & 0.50 & 0.50 & 1.00 & 3.00 & 3.00 & 0.33 & 1.00 & 3.03 & 1.00 & 2.00 & 0.25 & 0.09 \\
\hline 10 & 0.33 & 0.33 & 0.50 & 3.00 & 2.00 & 0.33 & 0.50 & 2.00 & 1.00 & 1.00 & 0.17 & 0.06 \\
\hline $\begin{array}{ll}\Lambda \mathrm{max}=10.50 ; \mathrm{CI}=0.0557 ; \mathrm{RI}=1.49 ; \\
\mathrm{CR}=0.0374\end{array}$ & 2.71 & 1.00 & 2.71 \\
\hline
\end{tabular}

Expert Factor Significance (importance) scoring is matrix in order to evaluate the Global Development Index of the industry. It is necessary to make the basic choice of matrix for which the maximum score an indicator (factor) can receive, e.g., 2, 3, 4 etc. The row indicator should be posi- 
tioned against the same in the column. The entire base value is used simultaneously for both indicators. The constructed matrix based on the expert knowledge is presented in Table 6. Using the results of the industry analysis explained in Step 3, the authors have identified all the factors affecting the forestry sector (industry) development (Table 4).

Step 4. To determine the stable probability of the industry development $\left(p_{i}\right)$ :

$$
\begin{aligned}
& p_{i}=\sum_{i=1}^{n} w_{i} \cdot F_{i} ; \\
& p_{r}=1-p_{i},
\end{aligned}
$$

where $p_{r}$ - the sectorial risk level.

Industry risk indicators (factors) are determined according to the industry development probability scale (see Table 7).

\begin{tabular}{|c|c|c|c|c|c|}
\hline \multirow{3}{*}{ 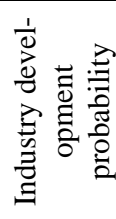 } & \multicolumn{5}{|c|}{ Industry development assessment } \\
\hline & Stable & $\begin{array}{c}\text { Positive } \\
\text { Trends }\end{array}$ & Uncertain & $\begin{array}{c}\text { Negative } \\
\text { Trends }\end{array}$ & Unstable \\
\hline & 1 & $0.5-1$ & 0.5 & $0.5-0$ & 0 \\
\hline \multirow{3}{*}{$\frac{\bar{d}}{\frac{\vec{d}}{\vec{a}}}$} & $\begin{array}{l}\text { Mini- } \\
\text { mum } \\
\text { risk }\end{array}$ & $\begin{array}{l}\text { Low } \\
\text { risk }\end{array}$ & $\begin{array}{l}\text { Moderate } \\
\text { risk }\end{array}$ & $\begin{array}{l}\text { High } \\
\text { risk }\end{array}$ & $\begin{array}{l}\text { Very high } \\
\text { risk }\end{array}$ \\
\hline & \multicolumn{2}{|c|}{$0-0.33$} & $0.33-0.66$ & \multicolumn{2}{|c|}{$0.66-1$} \\
\hline & \multicolumn{2}{|c|}{ Acceptable, stable } & Moderate & \multicolumn{2}{|c|}{ Intolerable } \\
\hline
\end{tabular}

Table 7. Probability assessment

Using the results of the industry analysis explained in Steps 1-3, the authors have identified all the factors affecting the risk assessment in the forestry sector (industry) (see Table 8).

Table 8. Values of normalised factors to calculate the industry risk

\begin{tabular}{|c|c|c|c|c|c|c|}
\hline 2012 & 2013 & 2014 & 2015 & 2016 & 2017 & 2018 \\
\hline F0 & F1 & F2 & F3 & F4 & F5 & F6 \\
\hline 0.50 & 1.00 & 1.00 & 1.00 & 1.00 & 1.00 & 1.00 \\
\hline 0.50 & 0.79 & 0.47 & 0.00 & 0.00 & 0.16 & 1.00 \\
\hline 0.50 & 0.66 & 1.00 & 0.00 & 0.59 & 0.79 & 0.52 \\
\hline 0.50 & 0.60 & 0.83 & 0.80 & 0.78 & 0.87 & 1.00 \\
\hline 0.50 & 0.88 & 1.00 & 1.00 & 1.00 & 1.00 & 1.00 \\
\hline 0.50 & 0.76 & 1.00 & 0.00 & 0.00 & 0.00 & 1.00 \\
\hline 0.50 & 0.38 & 0.82 & 0.78 & 0.25 & 0.00 & 1.00 \\
\hline 0.50 & 0.70 & 0.00 & 1.00 & 1.00 & 1.00 & 1.00 \\
\hline 0.50 & 0.00 & 0.00 & 0.19 & 0.28 & 0.31 & 0.31 \\
\hline 0.50 & 0.36 & 0.38 & 0.00 & 0.00 & 0.00 & 1.00 \\
\hline
\end{tabular}

After assessing the risk for the forestry sector (industry) (see Table 8), the stable probability of the industry development $\left(p_{i}\right)$ has been determined as explained in Step 4 (Table 9).

Table 9. Probability ( $p i$ ) of the stable development of the industry and determination of risk for the forestry sector

\begin{tabular}{|c|c|c|c|c|c|c|}
\hline \multirow{2}{*}{$\begin{array}{l}\text { Industry de- } \\
\text { velopment } \\
\text { factor }\end{array}$} & \multicolumn{6}{|c|}{$p_{i}$} \\
\hline & 2013 & 2014 & 2015 & 2016 & 2017 & 2018 \\
\hline 1 & 0.16 & 0.16 & 0.16 & 0.19 & 0.16 & 0.16 \\
\hline 2 & 0.15 & 0.09 & 0.00 & 0.01 & 0.04 & 0.19 \\
\hline 3 & 0.06 & 0.09 & 0.00 & 0.02 & 0.07 & 0.05 \\
\hline 4 & 0.02 & 0.02 & 0.02 & 0.03 & 0.03 & 0.03 \\
\hline 5 & 0.03 & 0.04 & 0.04 & 0.21 & 0.04 & 0.04 \\
\hline 6 & 0.16 & 0.21 & 0.00 & 0.00 & 0.00 & 0.21 \\
\hline 7 & 0.04 & 0.08 & 0.08 & 0.01 & 0.00 & 0.10 \\
\hline 8 & 0.03 & 0.04 & 0.04 & 0.09 & 0.04 & 0.04 \\
\hline 9 & 0.00 & 0.02 & 0.03 & 0.02 & 0.03 & 0.03 \\
\hline 10 & 0.02 & 0.02 & 0.00 & 0.00 & 0.00 & 0.06 \\
\hline $\begin{array}{l}\text { Development } \\
\text { Probability }\end{array}$ & 0.67 & 0.77 & 0.37 & 0.58 & 0.40 & 0.91 \\
\hline Assessment & Stable & High & & & High & Stable \\
\hline Risk level & 0.33 & 0.23 & 0.63 & 0.42 & 0.60 & 0.09 \\
\hline
\end{tabular}
(industry)

Table 8 demonstrates the normalisaton results of 10 factors used to calculate the industry risk in the forestry sector over a six-year time period. From Table 9 it is observed that probability for stable development of the industry and determination of risk for the forestry sector (industry) every year is from moderate and low to high risk.

In Table 9, the expected returns vary significantly since the risk is from low to high. Therefore, the results suggest that market development and sectoral risks could impact the level of operational risk. For the company it is necessary to capture the impact of macroeconomic variables on the company's ability to maintain and provide support in order to analyse the inidicators (factors) affecting the industrial sector's financial activity, as a result of the financial crisis (Gutu et al., 2015). It is also observed that financial disruptions have increased the degree of misallocation of inputs across firms, which naturally shows up as a decline in measured aggregate productivity, and the economy responds by reducing investment and reallocating capital toward the sector (Arellano et al., 2018; Gopinath et al., 2017).

The study has shown that the indicator of the volatility existence (Xe) of factors varies from $3 \%$ (min) to $28 \%$ (max) with an average of $13 \%$ (Table 3). The analysis of sectoral risk of the forestry sector over a six-year period (2013-2018) shows the cyclical nature of changes in the development of the industry and two periods (2015 and 2017) 
with a high level of sectoral risk. With the results obtained, the study should be supplemented by taking into account the impact of climate risk on the development of the sector.

\section{Conclusions}

Sectoral risk has been considered in the paper from the perspective of the aggregate competitiveness of sector representatives and the cyclical processes that take place in the forestry industry. A review of industry risk assessment methods has revealed two main groups of methods, each of which is associated with different dimensions that underlie the definition of industry risk. The highest significance in the expert assessment of factors has been given by economic profitability $(21 \%)$, export potential $(19 \%)$ and total value added (16\%), which is $56 \%$ of the total significance of the factors underlying the industry risk assessment.

The authors have presented the methodology for assessing sectoral risk based on the combined use of an expert method to assess the significance of factors of stable competitive development of the industry using AHP and statistical normalisation of heterogeneous indicators (factors) in the period dynamics. The authors have proposed a composite indicator of sustainable development as a measure of industry risk. The proposed method of assessing sectoral risk can be useful for government control bodies to select sectors of the national economy for evaluating development and financial audits, taking into account the results achieved in comparison with development plans. Our results and method can be added to the literature and analysis on sectoral risks, which currently lack in terms of decision support system areas for SMEs. Although it is recognised that the sectoral risk can arise from a range of sources, given that it is acknowledged that there is lower decision support system investment for SME and that such systems directly impact business risk, in this context it suggests that simple sectoral risk assessment can be attributed to decision support systems. Our results therefore support the case of increased investment in decision support for SMEs. It is also rather simple for SMEs to integrate sectoral risk as part of decision-making process that can influence investment during certain periods of time.

Additionally, good sectoral risk management would aim at reducing extreme losses, thereby reducing investment risk, and this would also be achieved from decision support system investment. Our study will be of particular value to investment decisions in emerging markets for SMEs and will help plan budgets. In future research plans, the authors propose, as one of the factors, introducing the bankruptcy probability of enterprises belonging to the industry.

\section{References}

Accornero, M., Cascarino, G., Felici, R., Parlapiano, F., \& Sorrentino, A. M. (2015). Sectoral risk in Italian banks. In Credit exposures to non-financial firms (pp. 1-32).

Aguilar, F., Blazier, M. A., Alavalapati, J., \& Vlosky, R. (2013). The global forest sector: changes, practices, and prospects. Taylor and Francis Group.

Allen, F., \& Gale, D. (2000). Financial contagion. Journal of Political Economy, 108, 1-33.

https://doi.org/10.1086/262109

Arellano, C., Bai, Y., \& Mihalache, G. (2018). Default risk, sectoral reallocation, and persistent recessions. Journal of International Economics, 112, 182-199. https://doi.org/10.1016/j.jinteco.2018.01.004

Arsić, S., Nikolić, D., Mihajlović, I., Fedajev, A., \& Živković, Ž. (2018). A new approach within ANPSWOT framework for prioritization of ecosystem management and case study of National Park Djerdap, Serbia. Ecological Economics, 146, 8595. https://doi.org/10.1016/j.ecolecon.2017.10.006

Arsić, S., Nikolić, D., \& Živković, Z. (2017). Hybrid SWOT - ANP - FANP model for prioritization strategies of sustainable development of ecotourism in National Park Djerdap, Serbia. Forest Policy and Economics, 80, 11-26. https://doi.org/10.1016/j.forpol.2017.02.003

Boulter, J. (2011). Approach for reporting on ecosystem services: incorporating ecosystem services into an organization's performance disclosure. GRI.

Cayir Ervural, B., Zaim, S., Demirel, O. F., Aydin, Z., \& Delen, D. (2018). An ANP and fuzzy TOPSISbased SWOT analysis for Turkey's energy planning. Renewable and Sustainable Energy Reviews, 82, 1538-1550. https://doi.org/10.1016/j.rser.2017.06.095

Central Statistical Bureau. (2020). Forestry in 2020, in Latvian [WWW Document].

Chen, J., \& Yang, Y. (2011). A fuzzy ANP-based approach to evaluate region agricultural drought risk. Procedia Engineering, 23, 822-827. https://doi.org/10.1016/j.proeng.2011.11.2588

Cvetkova, E. A. (2010). Assessment of sectoral risk example of Construction sector. Finance and Credit, 37, 44-47.

D’Amato, D., Li, N., Rekola, M., Toppinen, A., \& Lu, F. F. (2015). Linking forest ecosystem services to corporate sustainability disclosure: A conceptual 
analysis. Ecosystem Services, 14, 170-178. https://doi.org/10.1016/j.ecoser.2014.11.017

Düllmann, K., \& Masschelein, N. (2007). A tractable model to measure sector concentration risk in credit portfolios. Journal of Financial Services Research, 32, 55-79. https://doi.org/10.1007/s10693-007-0014-3

Evangelista, R., Lucchese, M., \& Meliciani, V. (2015). Business services and the export performances of manufacturing industries. Journal of Evolutionary Economics, 25, 959-981. https://doi.org/10.1007/s00191-015-0400-1

Gopinath, G., Kalemli-Özcan, Şe., Karabarbounis, L., \& Villegas-Sanchez, C. (2017). Capital allocation and productivity in south Europe. Quarterly Journal of Economics, 132, 1915-1967. https://doi.org/10.1093/qje/qjx024

Grošelj, P., \& Zadnik Stirn, L. (2015). The environmental management problem of Pohorje, Slovenia: A new group approach within ANP SWOT framework. Journal of Environmental Management, 161, 106-112. https://doi.org/10.1016/j.jenvman.2015.06.038

Gutu, L. M., Străchinaru, A. I., Străchinaru, A. V., \& Ilie, V. (2015). The macroeconomic variables' impact on industrial production in the context of financial crisis. Procedia Economics and Finance, 32, 1258-1267. https://doi.org/10.1016/s2212-5671(15)01503-8

Ho, W. (2008). Integrated analytic hierarchy process and its applications - A literature review. European Journal of Operational Research, 186, 211-228. https://doi.org/10.1016/j.ejor.2007.01.004

Hora, M., \& Klassen, R. D. (2013). Learning from others' misfortune: Factors influencing knowledge acquisition to reduce operational risk. Journal of Operations Management, 31, 52-61. https://doi.org/10.1016/j.jom.2012.06.004

Ito, K., \& Shimizu, J. (2015). Industry-Level competitiveness, productivity and effective exchange rates in East Asia. Asian Economic Journal, 29, 181-214. https://doi.org/10.1111/asej.12054

Ivlev, I., Kneppo, P., \& Barták, M. (2015). Method for selecting expert groups and determining the importance of experts' judgments for the purpose of managerial decision-making tasks in health system. Business Administration and Management, $18,57-72$. https://doi.org/10.15240/tul/001/2015-2-005

Merton, R. K., Fiske, M., \& Kendall, P. L. (1990). The focused interview: a manual of problems and procedures. Published by Free Press.

Nehrebecka, N. (2018). Sectoral risk assessment with particular emphasis on export enterprises in Poland. Zbornik Radova Ekonomskog Fakultet au Rijeci, 36, 677-700.
Postnikov, V., \& Spiridonov, S. (2013). Approach to increasing the level of consistency of expert opinion when selecting the variant of development of the data processing system. Science and Education of the Bauman MSTU, 13, 333-350. https://doi.org/10.7463/0613.0574220

Počs, R. (2016). Instrumentary for competitiveness analysis of the Latvian economy. Latvian Academy of Sciences, 70, 10-19.

Ray, S. C., \& Das, A. (2010). Distribution of cost and profit efficiency: Evidence from Indian banking. European Journal of Operational Research, 201, 297-307. https://doi.org/10.1016/j.ejor.2009.02.030

Saaty, T. L. (2004). Decision making - the Analytic Hierarchy and Network Processes (AHP/ANP). Journal of Systems Science and Systems Engineering, 13, 1-35. https://doi.org/10.1007/s11518-006-0151-5

Saaty, T. L. (1989). Decision making for leaders: The analytical hierarchy process for decisions in a complex world. European Journal of Operational Research, 42, 107-109. https://doi.org/10.1016/0377-2217(89)90066-0

Sevkli, M., Oztekin, A., Uysal, O., Torlak, G., Turkyilmaz, A., \& Delen, D. (2012). Development of a fuzzy ANP based SWOT analysis for the airline industry in Turkey. Expert Systems with Applications, 39, 14-24.

https://doi.org/10.1016/j.eswa.2011.06.047

Smimou, K. (2014). International portfolio choice and political instability risk: A multi-objective approach. European Journal of Operational Research, 234, 546-560. https://doi.org/10.1016/j.ejor.2013.01.024

Tapman, L. N. (2002). Risks in the economy. Unity, Moscow.

Vivel-Búa, M., Lado-Sestayo, R., \& Otero-González, L. (2018). Risk determinants in the hotel sector: Risk credit in MSMEs. International Journal of Hospitality Management, 70, 110-119. https://doi.org/10.1016/j.ijhm.2017.11.004

Yüksel, I., \& Dağdeviren, M. (2007). Using the analytic network process (ANP) in a SWOT analysis - A case study for a textile firm. Information Sciences, 177, 3364-3382. https://doi.org/10.1016/j.ins.2007.01.001

Zhang, M. (2018). Sectoral risk research about inputoutput structure of the United States. Physica A: Statistical Mechanics and its Applications, 491, 199-208. https://doi.org/10.1016/j.physa.2017.08.110

Zhu, X., Wei, L., Wu, D., \& Li, J. (2018). A general framework for constructing bank risk data sets. Journal of Risk, 21, 37-60. https://doi.org/10.21314/JOR.2018.393 